\title{
Analysis of Biomass-fired Boilers in a Polygeneration System for a Hospital
}

\author{
Danielle Bandeira de Mello Delgado ${ }^{1}$, Monica Carvalho ${ }^{*}$, Luiz Moreira Coelho Junior ${ }^{1}$, Ricardo \\ Chacartegui $^{2}$ \\ ${ }^{1}$ Graduate Program in Renewable Energy, Center of Alternative and Renewable Engineering, Federal University \\ of Paraíba. Cx Postal 5115, Cidade Universitária, João Pessoa, Paraíba, 58059-900, Brazil. \\ ${ }^{2}$ Energy Engineering Department, University of Seville, Camino de los Descubrimientos s/n, 41092, Seville, Spain. \\ Email: monica@cear.ufpb.br
}

\begin{abstract}
This study evaluates the types of biomass that can be used in boilers for the production of steam and hot water for the Lauro Wanderley University Hospital located in the city of João Pessoa, Paraíba, Brazil, using average cost of production and business model analysis (Business Model Canvas). The study was conducted to subsidize a system for the optimization of the energy resources to be adopted by the hospital, as the design of a product or service production system can identify opportunities to reduce costs and environmental damage. The energy demand of the hospital was surveyed. Only firewood, sugarcane bagasse and pellets were considered in the analysis, as these are the types of biomass allowed in the specified boiler. The results showed that the pellets were the costliest resource, whereas firewood exhibited the best results considering the average cost of production and the business model. This information supports more consistently the adequate inclusion of this resource in the hospital superstructure and, consequently, the optimization of the polygeneration system, allowing clearer verification of decreased costs and environmental impacts.
\end{abstract}

Keywords: Biomass, polygeneration system, cost of production, hospital.

\section{Introduction}

Over the last few years, the use of multiple energy sources in energy supply systems to guarantee reliability and improve energy use has been gaining attention [1-6]. Polygeneration, as it is more commonly known, is defined as the combined production of two or more energy services to reach the maximum use of the various energy sources used. Its main advantage is the efficient use of these sources, as it requires detailed study of the generation-consumption ratio, the reliability and continuity of the energy supply and the system's improvements compared to autonomous systems. Polygeneration and energy integration are promising tools for achieving better efficiency in the use of natural resources and, in most cases, also reducing the environmental impacts generated [2]. Examples of the application of polygeneration systems include the commercial [7-9], domestic [10-11], and industry [12-13] sectors

Some consumption units, such as hospitals, exhibit high energy consumption and require continuous and simultaneous electric and thermal energy [14-16]. Therefore, hospitals are excellent units with potential for deploying polygeneration systems, as their comfort conditions and electricity, hot water, heating and air conditioning demands must be continuously met. There are recent studies on the optimization of polygeneration systems in hospitals [17-19]. However, the optimal configuration of these systems still represents a complex problem due to the wide variety of technological options for energy supply and conversion and the large daily and annual variations in energy demands and in energy prices and rates. According to Shang and Kokossis [20], variability in energy demand requires a project methodology that results in efficient production systems (thermodynamic objective) that are able to adapt to different demand and market conditions (operational flexibility) and can operate with minimal economic costs.

Although the quantification of biomass use is a challenge, due to non-commercial uses, it is estimated that it can represent up to $14 \%$ of global primary energy consumption; in some developing countries, 
this share can increase to $34 \%$, reaching $60 \%$ in Africa [21]. Biomass availability is highly influenced by crop patterns and regional variations of weather and seasons [22]. In Brazil, the availability of biomass resource is mainly connected to the sugar and alcohol sector, paper and cellulose sector, agricultural residues, wood industry residues, energy forests and oleaginous plants [23]. Sugarcane bagasse presents the greatest potential for use in the short and medium terms, but other residues (rice straw and husk, wood bark) can also represent other promising sources of biomass in Brazil [24].

Apart from residential cooking purposes, the most direct use for biomass fuel is in boilers. The most frequent conversion technologies used in biomass boilers include step grate furnace, stationary grate furnace, stoker combustion, suspension combustion, and fluidized bed combustion [22]. Despite economic and environmental advantages [25-26], fouling, marketing, low heating value, storage, collection and handling are all associated problems when burning biomass in boilers [27]. A review on the challenges and opportunities associated with the use of biomass in energy conversion systems can be found in [28]. Sugarcane bagasse boilers have been evaluated on the basis of thermodynamics [29-30], economics [31], and the environment [32-33]. Firewood boilers have been the objective of several studies [34-36]. Biomass can be pressed into pellets, with regular shape and high density - the production and thermal utilization of pellets can be consulted in [37]. There are also several publications on different viewpoints of the utilization of biomass pellet boilers [38-40].

Hospitals around the world have benefitted from the use of biomass boilers [41-45], but currently biomass boilers are not employed in hospitals in Northeast Brazil. Despite a study that evaluated several possibilities for boiler biomass fuels in a Brazilian hospital [46], only one reported case of utilization of biomass in Midwest Brazil was found after an extensive, detailed review - in this case, sugarcane bagasse [47]. The integration of biomass in a polygeneration system would increase the participation of renewables in heat and power generation, minimizing the global impact of the hospital's energy supply system. Although biomass is not employed as a fuel in hospitals of Northeast Brazil, its utilization would present advantages from energy and economic points of view. However, the tropical climate, with no requirements for spatial comfort heating (only for sanitary hot water and steam), prevents the immediate economic viability of a biomass-based energy system. This highlights the need for the study presented herein, which analyzes the integration of biomass in optimized polygeneration systems.

Herein a business model was developed, and the average cost of production was analyzed to evaluate the use of three different types of biomass as energy resources for boilers for the production of hot water and steam in a polygeneration system planned for a hospital located in Northeast Brazil. The analysis is based on the superstructure established by Romero, Carvalho and Millar [17-18] and on the optimization results found by Carvalho et al. [19], in which biomass was one of the energy resources with the best results. Biomass represents an attractive option for Northeast Brazil, as this region counts with many biomass sources, including sugarcane bagasse, firewood, coconut husk, to name a few. Initiatives for the use of building construction waste could also represent important biomass sources. The results obtained herein showed that an adequate choice of biomass could reduce the energy costs of the hospital in $3 \%$ and $11 \%$, when utilizing firewood and sugarcane bagasse, respectively.

The structure of the paper is as following: firstly the methodology used to characterize the energy system is described, then the main characteristics of the hospital under study are described along with the energy framework. Secondly, the methodology is described, followed by main results and discussion.

\section{Methodology}

\subsection{Hospital Characterization}

The hospital studied was the Lauro Wanderley University Hospital (Hospital Universitário Lauro Wanderley - HU), located in Campus I of the Federal University of Paraíba (Universidade Federal da Paraíba-UFPB), João Pessoa, Paraíba, Brazil. The hospital encompasses an architectural complex of approximately $44,000 \mathrm{~m}^{2}$, of which approximately $9,000 \mathrm{~m}^{2}$ are under construction [48].

For the implementation of the polygeneration system, typical hospital energy demands were considered: electricity, hot water, steam and air conditioning. The electricity demand is the energy consumption from lighting, elevators and equipment and depends mainly on the size of the hospital. The 
hot water (used in the kitchen and laundry room) and steam (for sterilization) demands also depend on the size of the hospital (number of beds). The thermal comfort demands (heating and air conditioning) are strongly influenced by the local climate of the hospital facility. Due to the climate of João Pessoa, hot water demands for room heating are not necessary. Overall, the demands vary according to the climate and the operating mode of the hospital. The climate will influence the hourly demands for thermal comfort, and the operating mode of the hospital categorizes its operating days as "business days" or "weekends" (or holidays). The energy consumption of hospitals during weekends and holidays is very low, which is reflected in the measured electricity consumption.

To better represent the monthly influence of climate on the energy demands, the study period chosen was one year (twelve months). The hospital operation only varies throughout the year according to the type of day. Therefore, to characterize the hospital demands, two representative days were established (a business day and a weekend day) per month. Each day is divided into 24 hourly periods, totaling 576 different operating periods during the year.

Due to the availability of real electricity data, these data were used for the electricity demands. For the calculation of the representative hot water, steam and air conditioning energy demands (which do not depend on the geographic location of the hospital), the sequential application of the degree-day method [49], climate data [50], occupational data [51] and data obtained from energy audits [52] were used. The steam demand was considered to be constant during the period of use for the sterilization center, between 6 am and $8 \mathrm{pm}$, in addition to the demand from a thermal counter at the restaurant during lunch and dinner. The hot water demand has two contributing factors: the laundry room, which operates between 8 am and $6 \mathrm{pm}$, and internal use in the hospital, which operates 24 hours a day with no interruptions.

Based on this analysis, the hospital has the following annual energy demands: 2791 MWh of electricity, 1947 MWh of hot water, 138 MWh of steam and 2309 MWh of air conditioning. Electricity was charged using hourly seasonal rates, with differential rates for the peak and off-peak hours [53]. In the selected mode, the daily rate is Brazilian Real (BRL)\$129/MWh, and in the peak hours, between 6 pm and $9 \mathrm{pm}$, the contractual rate is BRL $\$ 199 / \mathrm{MWh}$.

The price of natural gas [55] does not have hourly or seasonal differentiation, and if any equipment that uses natural gas is setup, the costs will also include the connection to the delivery network (gas pipelines).

Similarly, the rate considered for diesel (BRL $\$ 149 / \mathrm{MWh}$ ) is not differentiated hourly or seasonally, and the setup costs of equipment that operate with diesel include storage tanks.

The biomass used in the optimization model proposed by Carvalho et al. [19] was sugarcane bagasse. The state of Paraíba has eight sugarcane plants distributed among 26 municipalities along the coastline, all near João Pessoa [56]. This energy source was initially considered to meet the hot water and steam demands of the hospital (using boilers). That model included only one type of resource and did not consider the others that could be used by the equipment or specific regional features.

In this context, given the specifications of the manufacturer and supplier of biomass-fired boilers, a study was required for closer approximation to the real conditions of biomass supply for the boilers in the proposed polygeneration system. In this sense, the analysis was restricted to sugarcane bagasse, firewood and wood pellets, which can be used in the specified equipment and are accessible to the hospital studied.

\subsection{Optimization Procedure: Description of the Superstructure and the Biomass Equipment}

The complexity of polygeneration systems in a synthesis problem can be captured by Mixed Integer Programming (MIP) and consists of three major steps [57], where the first step is the development of a representation of alternatives (superstructure of technologies and utilities). The second and third steps, are, respectively, the formulation of a mathematical program and its resolution, from which the optimal solution is determined. The superstructure shown in Figure 1 was designed to meet the energy demands of the hospital studied. 


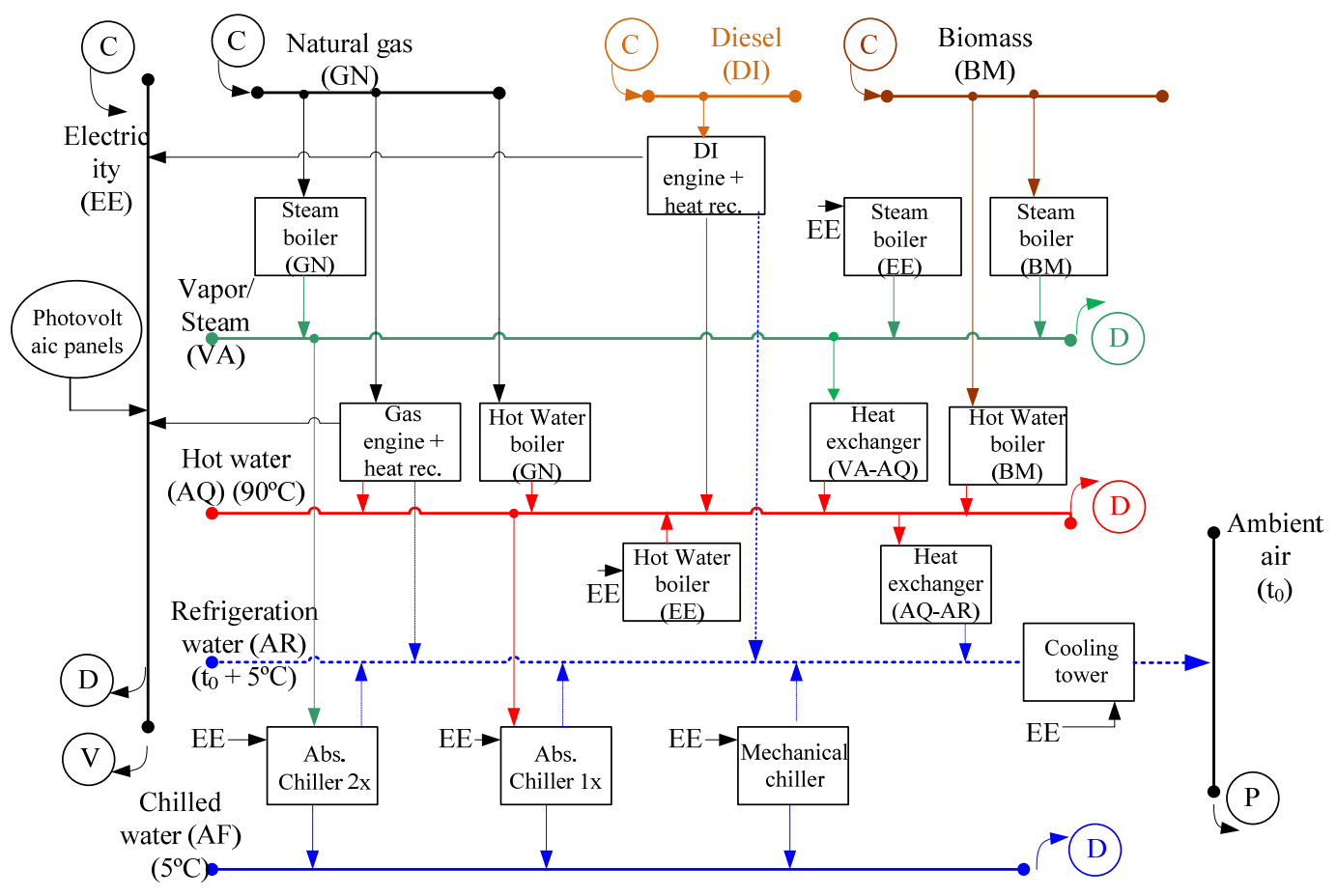

Figure 1. Polygeneration superstructure.

The hot water and steam demands will be met by boilers. The superstructure will use biomass, electric energy and diesel as fuel for this equipment. The analysis will only consider the boilers that use biomass for hot water and steam production to evaluate which biomass would be the most appropriate to supply these demands, especially considering the average cost of production. The analysis results will subsidize the optimization model proposed by Carvalho et al. [19] to analyze the sensitivity and resilience of the model results.

The calculation of the amount of fuel required uses the technical data provided by the boiler manufacturer with the following specifications: horizontal boiler for the production of $500 \mathrm{kgv} / \mathrm{h}$ for the use of biomass fuel (firewood, sugarcane bagasse and wood pellets), maximum allowable working pressure (MAWP) of 7 bar, 2-pass, steam temperature of $175^{\circ} \mathrm{C}$ and enthalpy of $662 \mathrm{kcal} / \mathrm{kg}$, working voltage of $220 \mathrm{~V}$, yield of $85 \%$ [58], the lower heating value (LHV) and the density of the materials.

\subsection{Characterization of Boiler Fuels}

Table 1. Boiler fuels.

\begin{tabular}{|c|c|c|c|c|c|c|}
\hline \multirow[t]{2}{*}{ PROPERTIES } & \multicolumn{6}{|l|}{ FUELS } \\
\hline & \multicolumn{2}{|c|}{ Firewood } & \multicolumn{2}{|c|}{ Sugarcane bagasse } & \multicolumn{2}{|c|}{ Pellet $[60]$} \\
\hline LHV & \multicolumn{2}{|c|}{$3100 \mathrm{kcal} / \mathrm{kg}[59]$} & \multicolumn{2}{|c|}{$2130 \mathrm{kcal} / \mathrm{kg}[59]$} & \multicolumn{2}{|c|}{$4000 \mathrm{kcal} / \mathrm{kg}$} \\
\hline Density & \multicolumn{2}{|c|}{$390 \mathrm{~kg} / \mathrm{m}^{3}$} & \multicolumn{2}{|c|}{$130 \mathrm{~kg} / \mathrm{m}^{3}$} & \multicolumn{2}{|c|}{$650 \mathrm{~kg} / \mathrm{m}^{3}$} \\
\hline Price & \multicolumn{2}{|c|}{$\mathrm{BRL} \$ 110 / \mathrm{m}^{3}[61]$} & \multicolumn{2}{|c|}{$\mathrm{BRL} \$ 16.80 / \mathrm{m}^{3}[62]$} & \multicolumn{2}{|c|}{$\mathrm{BRL} \$ 344.50 / \mathrm{m}^{3}[62]$} \\
\hline $\mathrm{MWh} / \mathrm{m}^{3}$ & \multicolumn{2}{|l|}{1.41} & \multicolumn{2}{|l|}{0.32} & \multicolumn{2}{|l|}{3.02} \\
\hline \multirow[t]{2}{*}{ Fuel required $\left(\mathrm{m}^{3}\right)$} & $\begin{array}{l}\text { Hot } \\
\text { Water }\end{array}$ & Steam & $\begin{array}{l}\text { Hot } \\
\text { Water }\end{array}$ & Steam & $\begin{array}{l}\text { Hot } \\
\text { Water }\end{array}$ & Steam \\
\hline & 1.587 .98 & 112.55 & 6.997 .03 & 495.94 & 645.55 & 45.69 \\
\hline
\end{tabular}

According to the boiler manufacturer's specifications, among the types of biomass that can be used in the equipment, the following will be analyzed: sugarcane bagasse, firewood and wood pellets. Considering the annual energy demands of the hospital, which are $1947 \mathrm{MWh}$ for hot water and 138 
MWh for steam, the LHV of the fuel, the boiler efficiency and material density, the amount required for each fuel was calculated, as presented in Table 1.

The conversion factor $1 \mathrm{kcal}=0.00116 \mathrm{kWh}$ was used, together with boiler efficiency $=85 \%$, to calculate the required amount of fuel. The rates for each fuel were obtained by consulting with suppliers. The price of firewood was BRL $\$ 55 /$ st, which included transportation and delivery to the hospital courtyard. This value is given per stere, and the conversion to cubic meter was performed using a packing factor of 0.5 [63].

The chart in Figure 2 compares the MWh value of the biomass types analyzed with the conventional electric energy rates provided by the electricity network, considering only the fuel price. The next topic presents the average cost of production of the analyzed energy resources available for the biomass-fired boilers.

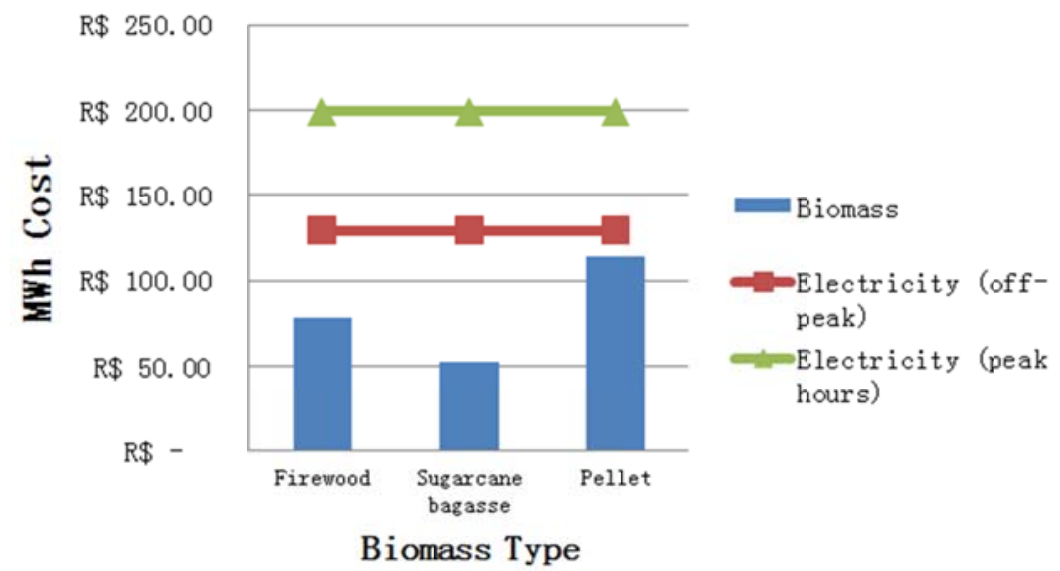

Figure 2. Comparison of MWh cost for the biomass types

\subsection{Average Cost of Production}

The price is set based only on the costs to evaluate the type of fuel to be used in the boiler (Table 2). The investment cost, which consists of the supply, transportation, setup and maintenance of the biomass-fired boiler, was obtained by consulting with suppliers, with the unit value of BRL $\$ 56,520.00$ [58]. The boiler can use the three types of biomass analyzed here; therefore, the initial cost is the same for all three. Transportation costs were calculated by Equation (1) [64]:

$$
C=1.5 L+(0.025 L) D
$$

$\mathrm{C}$ is the transportation cost (per $\mathrm{m}^{3} \mathrm{st}$ ), $\mathrm{L}$ is the price of Diesel (per liter), and D is the distance in $\mathrm{km}$.

Table 2. Total annual cost per biomass type

\begin{tabular}{|c|c|c|c|c|c|c|}
\hline \multirow{2}{*}{$\begin{array}{l}\text { Cost } \\
\text { Formation }\end{array}$} & \multicolumn{2}{|l|}{ Firewood } & \multicolumn{2}{|c|}{ Sugarcane Bagasse } & \multicolumn{2}{|l|}{ Pellets } \\
\hline & Hot Water & Steam & Hot Water & Steam & Hot Water & Steam \\
\hline Boiler Cost (BRL $\$)$ & $56,520.00$ & $56,520.00$ & $56,520.00$ & $56,520.00$ & $56,520.00$ & $56,520.00$ \\
\hline Boiler Transportation (BRL\$) & $13,800.00$ & $13,800.00$ & $13,800.00$ & $13,800.00$ & $\mathbb{1 3}, 800.00$ & $13,800.00$ \\
\hline Fuel $\left(\mathrm{m}^{3}\right)$ & $1,587.98$ & 112.55 & $6,997.03$ & 495.94 & 645.55 & 45.69 \\
\hline Fuel Price $\left(\mathrm{R} \$ / \mathrm{m}^{3}\right)$ & 110.00 & 110.00 & 16.80 & 16.80 & 344.50 & 344.50 \\
\hline Total Fuel Cost $\left(\mathrm{BRL} \$ / \mathrm{m}^{3}\right)$ & $174,677.80$ & $12,375.00$ & $117,550.10$ & $8,331.79$ & $222,391.97$ & $15,740.20$ \\
\hline Transportation Cost $\left(\mathrm{BRL} \$ / \mathrm{m}^{3}\right)$ & \multicolumn{2}{|c|}{ (included in fuel price) } & 8.52 & 8.52 & $\mathbb{1} 3.95$ & 13.95 \\
\hline Transportation Cost* (BRL\$) & \multicolumn{2}{|c|}{ (included in fuel price) } & $62,595.43$ & $4,436.68$ & $\mathbb{1 1}, 063.16$ & 783.01 \\
\hline TOTAL ANNUAL COST (BRL\$) & $244,997.80$ & $82,695.00$ & $250,465.53$ & $83,088.47$ & $303,775.13$ & $86,843.21$ \\
\hline
\end{tabular}


The distance considered in the transportation calculation was $45 \mathrm{~km}$. The diesel price used in the calculation was BRL\$3.10, which is the average price charged by gas stations in the state. Additionally, one cubic meter of sugarcane was considered to be equal to one stere meter $(1 \mathrm{~m} 3=1 \mathrm{~m} 3 \mathrm{st})$.

In the case of the pellets, the closest supplier is located $120 \mathrm{~km}$ away [65]. The average diesel price was considered to be BRL\$3.10.

Furthermore, in the case of firewood, the value presented in Table 1 includes the transportation cost and a boiler service life of 15 years; therefore, the evaluation of the annual energy demand in this period will be considered.

A $17 \%$ goods and services tax rate was only considered for the pellets, as the supplier is located in a different state (Pernambuco). The supply fee of $5 \%$ refers to the loading and unloading of the material.

\subsection{Business Plan (Business Model Canvas)}

A business plan was created for the implementation of the enterprise proposed herein, which is the use of biomass in the hospital boilers. The use of a business plan allows a clearer evaluation of the possibilities of success in the attempt to decrease the risks of the enterprise and according to Dornelas [66], the business plan is a fundamental part of the entrepreneurial process. Figure 3 presents the business model triad of objective, business process and result for the model proposed herein.

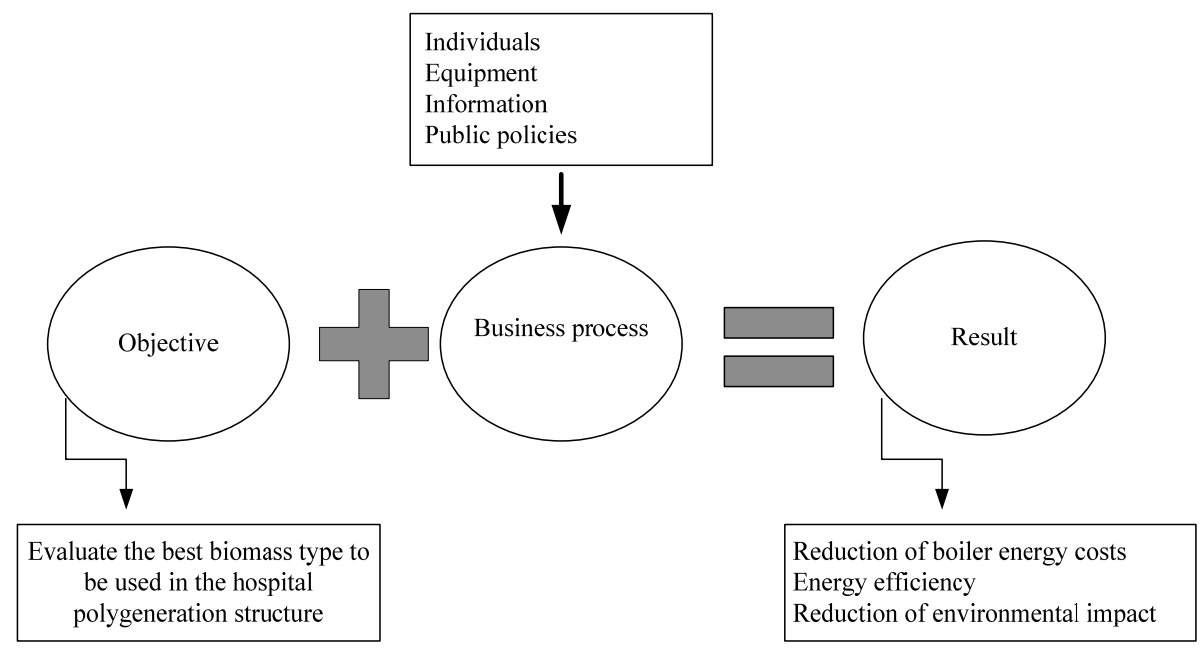

Figure 3. Enterprise triad

The Business Model Canvas is a simple model that describes how an organization generates, exchanges and receives value. In this case the methodology is applied to identify the pathway for a sustainable implementation of biomass, identifying the whole chain. It provides a general overview of the whole system associated to the business. The blocks cover the four main areas: customers, supply, infrastructure and financial viability. Three models will be developed, one for each analyzed biomass: firewood, sugarcane bagasse and wood pellets. The nine blocks used to define the Business Model Canvas are:

Main Partnerships. This block explores the partners required for the business to be successful. The role of the key suppliers, the partnerships required for the acquisition of resources and the consequent reduction of risks are presented.

Cost Structure. This topic is aimed at the cost analysis required for the efficiency and good performance of the business,.

Main Activities. The key activities of the business. The most important activities with the highest impact on business success, which offer a value proposition, should be described.

Main Resources. The main resources of an enterprise should be listed in the model to offer what is proposed. The indicated resources are material, financial, human and intellectual. 
Value Proposition. The value proposition presented here will be the justification, which is the reason for the use of one fuel instead of another. This section describes the products and services that aggregate value for each customer segment.

Customer Relationships. The hospital is the large consumer considered in the enterprise. Because the hospital is a large-scale consumption unit that requires reliable and continuous service, this block is analyzed carefully.

Channels. Channels represent the existing communication mechanisms of the business. The form of dissemination and the feedback from the customer in the enterprise are important requirements for the formation of this block.

Revenue Models. This component addresses the revenues generated by the enterprise. In the model proposed herein, the revenue will be analyzed based on comparison with other energy resources that could be used in the boilers.

Customer Segments. The customer is the most important part of any business. This block should inform the needs, behavior and attributes of each customer segment.

\section{$3 \quad$ Results and Discussion}

Table 3. Business model canvas - FIREWOOD

\begin{tabular}{|c|c|c|c|c|}
\hline \multirow{3}{*}{$\begin{array}{l}\text { Main Partnerships } \\
\text { Legal firewood suppliers } \\
\text { located at a } 100 \mathrm{~km} \text { radius } \\
\text { from the hospital; } \\
\text { Transportation companies; } \\
\text { Biomass-fired boiler } \\
\text { supplier; } \\
\text { Financial institutions with } \\
\text { credit lines for energy } \\
\text { efficiency programs. }\end{array}$} & Main Activities & \multirow{3}{*}{$\begin{array}{l}\text { Value Proposition } \\
\text { Use of unconventional } \\
\text { renewable energy } \\
\text { resources; } \\
\text { Reduction of electricity } \\
\text { expenses; } \\
\text { Energy efficiency in } \\
\text { thermal comfort, safety } \\
\text { and hygiene; } \\
\text { Environmental education } \\
\text { and awareness. }\end{array}$} & Customer Relationships & \multirow{3}{*}{$\begin{array}{l}\text { Customer } \\
\text { Segments } \\
\text { Individuals } \\
\text { in need of } \\
\text { hospital } \\
\text { care. }\end{array}$} \\
\hline & $\begin{array}{l}\text { Provision of public and } \\
\text { free medical hospital } \\
\text { service, continuously } \\
\text { and safely. }\end{array}$ & & $\begin{array}{l}\text { Safe and efficient hospital } \\
\text { customer service }\end{array}$ & \\
\hline & $\begin{array}{l}\text { Main Resources } \\
\text { Human Resources; } \\
\text { Hospital Management; } \\
\text { Firewood. }\end{array}$ & & $\begin{array}{l}\text { Channels } \\
\text { Energy audits; } \\
\text { Management awareness } \\
\text { campaigns; } \\
\text { Projects to improve } \\
\text { efficiency. }\end{array}$ & \\
\hline \multicolumn{3}{|c|}{$\begin{array}{l}\text { Cost Structure } \\
\text { Purchase of biomass-fired boiler } \\
\text { Purchase of firewood - Transportation - Storage } \\
\text { Manpower Maintenance and Operation }\end{array}$} & \multicolumn{2}{|c|}{$\begin{array}{l}\text { Revenue Models } \\
\text { Reduction of energy bill expenses. }\end{array}$} \\
\hline
\end{tabular}

Table 4. Business model canvas - sugarcane bagasse

\begin{tabular}{|c|c|c|c|c|}
\hline \multirow{3}{*}{$\begin{array}{l}\text { Main Partnerships } \\
\text { Sugar, alcohol and } \\
\text { distillates plants at a } \\
50 \mathrm{~km} \text { radius from the } \\
\text { hospital; } \\
\text { Sugarcane producers; } \\
\text { Transporters; } \\
\text { Biomass-fired boiler } \\
\text { supplier }\end{array}$} & Main Activities & \multirow{3}{*}{$\begin{array}{l}\text { Value Proposition } \\
\text { Use of unconventional } \\
\text { renewable energy resource; } \\
\text { Reduction of electricity } \\
\text { expenses; } \\
\text { Energy efficiency for thermal } \\
\text { comfort, safety and hygiene; } \\
\text { Environmental education and } \\
\text { awareness. }\end{array}$} & Customer Relationships & \multirow{3}{*}{$\begin{array}{l}\text { Customer } \\
\text { Segments } \\
\text { Individuals } \\
\text { in need of } \\
\text { hospital } \\
\text { care. }\end{array}$} \\
\hline & $\begin{array}{l}\text { Provision of public and free } \\
\text { medical hospital service. }\end{array}$ & & $\begin{array}{l}\text { Safe and efficient } \\
\text { hospital customer service }\end{array}$ & \\
\hline & $\begin{array}{l}\text { Main Resources } \\
\text { Human Resources; } \\
\text { Hospital Management; } \\
\text { Sugarcane bagasse. }\end{array}$ & & $\begin{array}{l}\text { Channels } \\
\text { Energy audits; } \\
\text { Awareness campaigns; } \\
\text { Projects to improve } \\
\text { efficiency. }\end{array}$ & \\
\hline \multicolumn{3}{|c|}{$\begin{array}{l}\text { Cost Structure } \\
\text { Purchase of biomass-fired boiler } \\
\text { Purchase of sugarcane bagasse - Transportation - Storage } \\
\text { Manpower }\end{array}$} & \multicolumn{2}{|c|}{$\begin{array}{l}\text { Revenue Models } \\
\text { Reduction of energy bill expenses. }\end{array}$} \\
\hline
\end{tabular}


Table 5. Business model canvas - pellets

\begin{tabular}{|c|c|c|c|c|}
\hline \multirow{8}{*}{$\begin{array}{l}\text { Key } \\
\text { Partnerships } \\
\text { Wood pellet } \\
\text { supplier; } \\
\text { Interstate } \\
\text { transporters; } \\
\text { Biomass-fired } \\
\text { boiler supplier. }\end{array}$} & Key Activities & \multirow{8}{*}{$\begin{array}{l}\text { Value Proposition } \\
\text { Use of unconventional renewable } \\
\text { energy resource; } \\
\text { Reduction of electricity expenses; } \\
\text { Energy efficiency in the thermal } \\
\text { comfort, safety and hygiene; } \\
\text { Environmental educational and } \\
\text { awareness. }\end{array}$} & Customer Relationships & \multirow{8}{*}{$\begin{array}{l}\text { Customer } \\
\text { Segments } \\
\text { Individuals } \\
\text { in need of } \\
\text { hospital } \\
\text { care. }\end{array}$} \\
\hline & 1. Provision of public and & & Safe and efficient & \\
\hline & free medical hospital service & & hospital customer service & \\
\hline & Key Resources & & Channels & \\
\hline & Human Resources; & & Energy audits; & \\
\hline & Hospital Management; & & awareness campaigns; & \\
\hline & Wood pellets. & & Projects to improve & \\
\hline & & & efficiency. & \\
\hline \multirow{3}{*}{\multicolumn{3}{|c|}{$\begin{array}{l}\text { Cost Structure } \\
\text { Purchase of biomass-fired boiler } \\
\text { Purchase of pellets - Storage }\end{array}$}} & \multirow{4}{*}{\multicolumn{2}{|c|}{$\begin{array}{l}\text { Revenue Models } \\
\text { Reduction of energy bill expenses. }\end{array}$}} \\
\hline & & & & \\
\hline & & & & \\
\hline \multicolumn{3}{|c|}{ Maintenance } & & \\
\hline
\end{tabular}

For the analysis of the different raw biomass sources proposed in this study, three business models were designed, as represented in Tables 3, 4 and 5, one for each type of energy resource to be used in the boilers.

The objective of this study was to analyze three types of biomass to identify the most viable for use as an energy resource in boilers for the production of hot water and steam in a hospital in Paraíba.

The analysis of the average cost of production for firewood, sugarcane bagasse and wood pellets resulted in the total annual costs presented in Figure 4. This information, in addition to that contained in the three business models presented here, will be used as parameters for the sensitivity analyses proposed by Carvalho et al. [19] and as decision criteria for the type of biomass that should be used in the boilers of the hospital superstructure.

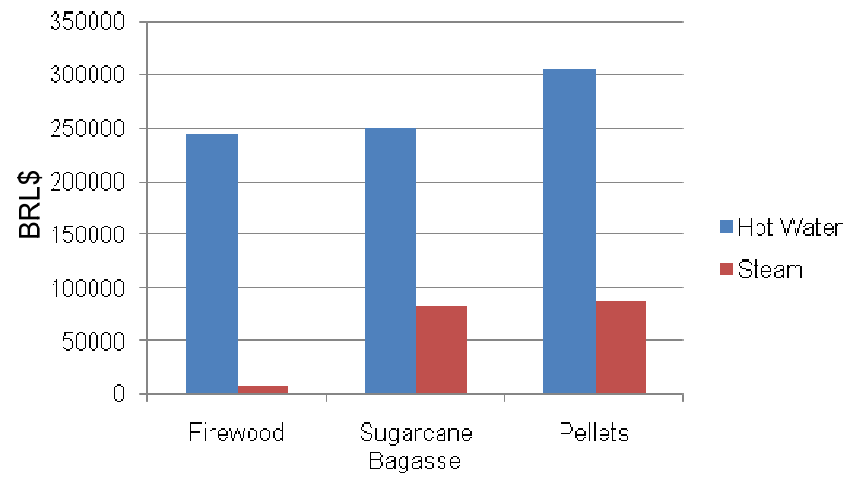

Figure 4. Total annual cost

The total annual cost was the main criterion for the selection of the biomass, because the situations are very similar among the business models. The pellets have the advantage of being able to be stored, as they are more compact; however, this was the resource with the highest annual cost.

In the composition of the cost of sugarcane bagasse, the transport corresponds to about $53.25 \%$ of the biomass value. In pellets the cost of transport is about $5 \%$ of the value of this resource. For firewood, in the assessment of the cost of the evaluated resource, the value of the transport was already included. The study showed that the composition of the costs for the use of biomass in boilers faces some geographical limitations, and because it is a dynamic market, where a certain negotiation pattern does not yet exist, the inherent issues were not evaluated such as the storage and adequacy necessary for pretreatment of these resources. 
Consideration of greenhouse gases throughout the life cycle of different types of biomass can be accomplished using the Life Cycle Assessment Methodology [67-69]. Utilization of the Ecoinvent database [70] within software SimaPro 8.4.0.0 [71], and environmental impact evaluation method IPCC 2013 GWP 100a [72] for the utilization of firewood in a boiler yielded $0.0721 \mathrm{~kg} \mathrm{CO}_{2}$-eq/ $\mathrm{kWh}$ of heat produced. Sugarcane bagasse and pellets resulted in, respectively, 0.0479 and $0.0595 \mathrm{~kg} \mathrm{CO}_{2}$-eq/ $\mathrm{kWh}$ of heat produced in a boiler. Utilizing data on the emissions associated with the consumption of electricity directly from the low voltage grid in Brazil (for year 2015) [69], the production of heat in an electric boiler yields $0.332 \mathrm{~kg} \mathrm{CO}$-eq/kWh of heat produced. The considerable carbon savings are obvious. Utilization of firewood to meet the hot water demands of the hospital emits approximately $140.379 \mathrm{~kg}$ $\mathrm{CO}_{2}$-eq/year, which is $78 \%$ lower than electric boilers (646.404 $\mathrm{kg} \mathrm{CO}_{2}$-eq/year).

In the comparison between the average cost of production of firewood and sugarcane bagasse, firewood has a slight advantage $(2.18 \%)$ in relation to the annual cost of sugarcane bagasse. In addition to the lower cost, it is easier to purchase firewood than sugarcane bagasse in the state of Paraíba because the supply of the latter, according to the state harvest, might not be continuous.

Table 6 presents the costs, in BRL, of the MWh for each type of biomass analyzed. The cost of firewood MWh is $15.17 \%$ lower than that of electricity in off-peak hours and $45 \%$ lower in peak hours. For sugarcane bagasse, these values are $13.9 \%$ and $44.19 \%$, respectively.

Table 6. Comparison of fuel and electricity costs.

\begin{tabular}{l|l}
\hline Fuel & MWh Cost (BRL\$/MWh) \\
\hline Firewood & BRL\$ 109.42 \\
\hline Sugarcane Bagasse & BRL\$ 111.06 \\
\hline Pellets & BRL\$ 155.83 \\
\hline Electricity - Off-Peak & BRL\$ 129.00 \\
\hline Electricity - Peak & BRL $\$ 199.00$ \\
\hline
\end{tabular}

For the pellets, the cost of the MWh is $17.21 \%$ higher than the cost of electricity in the off-peak hours. However, when compared to electricity at peak hours, the MWh cost is $21.69 \%$ lower.

With the definition of additional equipment and processes capital expenditures are defined and the main economic indicator for the hospital is defined.

When considering that the hospital could be supplied by conventional sources of energy (no cogeneration, no trigeneration, no biomass or solar energy), the total annual cost associated with meeting the energy demands was $\mathrm{R} \$ 931,897 /$ year [73]. This configuration installed natural gas boilers to produce heat, purchased electricity from the grid, and utilized mechanical chillers.

However, when solving the model without any restrictions, the optimal economic configuration when firewood was available included firewood boilers for the production of heat, mechanical chillers, 200 photovoltaic (PV) panels, and purchased electricity from to grid to meet the demands of the hospital at an annual cost of $\mathrm{R} \$ 904,267 /$ year. The same biomass-based configuration was obtained when sugarcane bagasse was utilized, yielding an annual cost of $\mathrm{R} \$ 835,031 /$ year (sugarcane bagasse boilers, $200 \mathrm{PV}$ panels, and mechanical chillers) [73]. However, when pellets were available, the configuration of the system was based on natural gas boilers, with an annual cost of $\mathrm{R} \$ 972,486$ (including $200 \mathrm{PV}$ panels and mechanical chillers). In this case, it can be seen how the optimization procedure takes advantage of biomass (in the cases of firewood and sugarcane bagasse), improving the economic performance of the overall energy supply system, when compared with the reference system, with annual costs that are $3 \%$ and $11 \%$ lower, respectively, for firewood and sugarcane bagasse.

\section{Conclusions}

The adoption of more efficient and less expensive equipment and fuels that generate fewer environmental emissions should be analyzed carefully by companies, especially public agencies, as it will reflect directly on the brand image for target customers and will also add value to the adopted resources.

The MWh cost of sugarcane bagasse (52.5 BRL\$/MWh), considering only the fuel cost, is lower than that of firewood and pellets (78 and $114 \mathrm{BRL} \$ / \mathrm{MWh}$, respectively). However, the indirect costs, 
especially those related to transportation, supply and storage of sugarcane bagasse, evened out the final costs of biomass, reducing the economic attractivity of sugacane biomass (final cost 111 BRL $\$ / \mathrm{MWh}$, in comparison with 109 and 155 for firewood and pellets, respectively)

Analysis and detailed study of the results and the business models regarding the choice of biomass for the boiler showed that firewood was the most viable and lowest-cost resource. This information supports with more consistency the inclusion of this resource in the hospital superstructure and, consequently, the optimization of the polygeneration system, allowing clearer verification of decreased costs and environmental impacts.

Acknowledgments. Monica Carvalho would like to thank the National Council for Scientific and Technological Development (CNPq), projects no 475879/2013-9 and no 303199/2015-6.

\section{References}

1. R. H. Williams et al., "Advanced energy supply technologies", World energy assessment: energy and the challenge of sustainability, pp. 273-329, 2000.

2. L. M. Serra et al., "Polygeneration and efficient use of natural resources", Energy, 34, pp. 575-586, 2009.

3. Y. Chen, T. A. Adams, and P. I. Barton, "Optimal design and operation of flexible energy polygeneration systems", Industrial \& Engineering Chemistry Research, 50.8, pp. 4553-4566, 2011.

4. Y. E. Yuksel, and M. Ozturk, "Thermodynamic Modeling of an Integrated Energy System for Poly-generation Design." Progress in Clean Energy, Vol. 1, Springer International Publishing, pp. 21-39, 2015.

5. A. Rong, and R. Lahdelma, "Role of polygeneration in sustainable energy system development challenges and opportunities from optimization viewpoints," Renewable and Sustainable Energy Reviews, vol. 53, pp. 363-372, 2016.

6. S. Murugan, and B. Horák, "Tri and polygeneration systems-A review," Renewable and Sustainable Energy Reviews, vol.60, pp 1032-1051, 2016.

7. P. Liu, E. N. Pistikopoulos, and Z. Li, "An energy systems engineering approach to the optimal design of energy systems in commercial buildings", Energy Policy 8.8, pp. 4224-4231, 2010.

8. C. Rubio-Maya, J. Uche, and J. Pacheco-Ibarra, "Feasibility analysis of a combined cooling-heatingpower and desalted water plant for a non-residential building" Int. J. Energy Environ. Eng, 2, pp. 33-41, 2011.

9. C. Rubio-Maya et al., "Design optimization of a polygeneration plant fuelled by natural gas and renewable energy sources", Applied Energy, 88.2, pp. 449-457, 2011.

10.G. Kyriakarakos, and G. Papadakis, "Polygeneration Microgrids for Residential Applications", Handbook of Clean Energy Systems, 2015.

11.P. Kazempoor, V. Dorer, and F. Ommi, "Modelling and Performance Evaluation of Solid Oxide Fuel Cell for Building Integrated Co-and Polygeneration", Fuel Cells 10.6, pp. 1074-1094, 2010.

12.A. Piacentino, and F. Cardona. "An original multi-objective criterion for the design of small-scale polygeneration systems based on realistic operating conditions", Applied thermal engineering, 28.17, pp. 2391-2404, 2008.

13.U. Sahoo et al., "Scope and sustainability of hybrid solar-biomass power plant with cooling, desalination in polygeneration process in India", Renewable and Sustainable Energy Reviews, 51, pp. 304-316, 2015.

14.D. Ziher, A. Poredos, "Economics of a trigeneration system in a hospital", Applied Thermal Engineering, vol.7, pp.680-687, 2006.

15.P. Arcuri, G. Florio, and P. Fragiacomo, "A mixed integer programming model for optimal design of trigeneration in a hospital complex", Energy, 32 (8), pp.1430-1447, 2007.

16.M. A. Lozano et al., "Structure optimization of energy supply systems in tertiary sector buildings", Energy and Buildings, 41 (10), pp.1063-1075, 2009.

17.A. Romero, M. Carvalho, D. L. Millar, "Application of a polygeneration optimization technique for a hospital in Northern Ontario", Transactions of the Canadian Society of Mechanical Engineering, vol.1, 2014.

18.A. Romero, M. Carvalho, D. L. Millar, "Biomass and solar thermal energy in the synthesis and optimization of a polygeneration system". In: V Congresso Brasileiro De Energia Solar, 2014. 
19.M. Carvalho, R. Charcategui, L. M. Coelho Junior, D. B. M. Delgado, "Optimization of Energy Supply and Conversion in a Northeast Brazil Hospital: Use of photovoltaic panels". In: 23rd ABCM International Congress Of Mechanical Engineering, 2015.

20.Z. Shang, A. Kokossis, "A systematic approach to the synthesis and design of flexible utility systems", Chemical Engineering Science, 60, pp. 4431-4451, 2005.

21.Brazilian Agency of Electricity (ANEEL). Brazilian Electricity Atlas. Chapter 5: availability of resources and consumption of biomass. Available at: http://www2.aneel.gov.br/aplicacoes/atlas/biomassa/5_2.htm

22.Asian Productivity Organization. Biomass as Fuel in Small Boilers. Tokyo: APO, 2009.

23.E. S. Lora, and R. V. Andrade, "Biomass as energy source in Brazil", Renewable and Sustainable Energy Reviews 13.4, pp. 777-788, 2009.

24.P. Anselmo Filho, and O. Badr, "Biomass resources for energy in North-Eastern Brazil", Applied Energy, 77.1, pp. 51-67, 2004.

25.L. Rosendahl, "Biomass combustion science, technology and engineering," Elsevier, 2013.

26.S. V. Vassilev, C. G. Vassileva, and V. S. Vassilev, "Advantages and disadvantages of composition and properties of biomass in comparison with coal: an overview", Fuel, 158, pp. 330-350, 2015.

27.R. Saidur et al., "A review on biomass as a fuel for boilers", Renewable and sustainable energy reviews, 15.5, pp. 2262-2289, 2011.

28.E. Thiffault et al., "Mobilisation of forest bioenergy in the boreal and temperate biomes: Challenges, opportunities and case studies", Academic Press, 2016.

29.S. Fujii et al., "Material and heat flow analysis in thermal energy storage and transport system utilizing unused heat from bagasse boiler", Mechanical Engineering Journal, 3.5,16-00334, 2016.

30.E. F. Cortes-Rodríguez, S. A. Nebra, and J. H. Sosa-Arnao, "Experimental efficiency analysis of sugarcane bagasse boilers based on the first law of thermodynamics", Journal of the Brazilian Society of Mechanical Sciences and Engineering, 39.3, pp.1033-1044, 2017.

31.L. E. Rincón et al., "Techno-economic analysis of the use of fired cogeneration systems based on sugar cane bagasse in south eastern and mid-western regions of Mexico", Waste and biomass valorization, 5.2, pp. 189-198, 2014.

32.M. H. Rocha et al. "Life cycle assessment (LCA) for biofuels in Brazilian conditions: a meta-analysis", Renewable and Sustainable Energy Reviews, 37, pp. 435-459, 2014.

33.D. A. L. Silva et al., "Life cycle assessment of the sugarcane bagasse electricity generation in Brazil", Renewable and Sustainable Energy Reviews, 32, pp. 532-547, 2014.

34.A. N. N. A. Majchrzycka, "Comparative analysis of individual house heating system based on electricity and combustion of alternative and fossil fuels", Wind energy, 10.53, 6-07, 2016.

35.J. D. Stephen et al., "Biomass for residential and commercial heating in a remote Canadian aboriginal community", Renewable Energy 86 (2016): 563-575.

36.L. Paolotti et al., "Economic and environmental assessment of agro-energy wood biomass supply chains", Biomass and Bioenergy, 97, pp. 172-185, 2017.

37.I. Obernberger, and G. Thek, "The pellet handbook", Earthscan Ltd, 2010.

38.B. Monteleone et al., "Life cycle analysis of small scale pellet boilers characterized by high efficiency and low emissions", Applied Energy, 155, pp. 160-170, 2015.

39.L. Carvalho et al., "Performance of a pellet boiler fired with agricultural fuels", Applied energy, 104, pp. 286-296, 2013.

40.A. Žandeckis et al., "Solar and pellet combisystem for apartment buildings: Heat losses and efficiency improvements of the pellet boiler", Applied energy, 101, pp. 244-252, 2013.

41.J. G. Sanz-Calcedo et al., "Efficiency of a biomass boiler in a hospital center. Use of olive crushing stones to produce heat", DYNA 86.3 (2011): 343-349.

42.Hamworthy. Whitchurch Community Hospital case study. 2017. Available at: https://www.hamworthyheating.com/case-studies/hospital-boilers/whitchurch-community-hospital-case-study

43.Uniconfort. Two Hospitals Choose Solid Biomass Boilers To Heat The Premises. Available at: https://www.uniconfort.com/en/references/biomass-in-the-hospital.html.

44.US Department of Energy. Oregon Hospital Heats Up with a Biomass Boiler. Available at: https://energy.gov/articles/oregon-hospital-heats-biomass-boiler 
45.M. Daskalakis and V. Iyer, "Finding energy savings with a biomass boiler: biomass boiler saves hospital money, energy", Heating/Piping/Air Conditioning Engineering, 81.6, 2009.

46.R. P. Francisco, "Estudo termoquímico da queima de combustíveis em caldeiras usando balanços de energia", MSc. dissertation, Universidade Federal de São João Del-Rei, 2012. [In Portuguese].

47.Globo.Com. Hospital saves $\mathrm{R} \$ 6,3$ million with energy from donated sugarcane bagasse. Available at: http://g1.globo.com/sp/ribeirao-preto-franca/noticia/2015/10/hospital-economiza-r-63-milhoes-com-energia-debagaco-de-cana-doada.html [In Portuguese].

48.EBSERH, Brazilian Company of Hospital Services. Lauro Wanderley University Hospital/UFPB: Design of assistance services and management of teaching and research. Available at: http://www.ebserh.mec.gov.br/ images/pdf/contratos_adesao_huf/ufpb/dimensionamento_de_servicos_hulw_ufpb.pdf $>$ [In Portuguese].

49.D. G. Erbs, S. A. Klein, and W. A. Beckman, "Estimation of degree-days and ambient temperature bin data from monthly-average temperatures", ASHARE Journal, 25 (6), pp. 60-65, 1983.

50.CLIMATICUS 4.2. Climate Data Base. Design strategies for 58 Brazilian cities. INMET 1961-1990 Database. Beta Version. Faculty of Architecture and Urbanism of the São Paulo University - Department of Technology Laboratory of environmental comfort and energy efficiency, Available at: www.fau.usp.br/pesquisa/laboratorios/ labaut/conforto/Climaticus_2011(beta).xlsm

51.M. H. A. Nepote, I. U. Monteiro, E. Hardy, "Association between operational indices and occupation rates of a general surgery center", Rev. Latino-Am. Enfermagem [online], 17 (4), 2009.

52.M. M. D. Araújo, "Methodological contribution for the exergy diagnosis of thermal and electrical systems - study case at the Lauro Wanderley University Hospital" M.Sc. dissertation in Mechanical Engineering, Department of Mechanical Engineering, Federal University of Paraíba, 2004. [In Portuguese].

53.Energisa. Energisa Paraíba, Available at: http://www.energisa.com.br/Paginas/informacoes/taxas-prazos-enormas/tipos-tarifas.aspx [In Portuguese].

54.PBGÁS, Gas Company of Paraíba. Tariffs. Available at: http://www.pbgas.com.br/?page_id=1477. [In Portuguese].

55.Nova Cana, Sugar and Ethanol companies in the state of Paraíba. Available: http://www.novacana.com/usinasbrasil/nordeste/paraiba/ [In Portuguese].

56.I. E. Grossmann, J. A. Caballero, and H. Yeomans, "Advances in mathematical programming for the synthesis of process systems" Latin American Applied Research;30(4), pp. 263-284,2000.

57.MULTiNOX, MULTINOX Of Brasil. Available at: http://www.multinoxdobrasil.com/caldeiras.html [In Portuguese].

58.Brasil, EPE, Energy Research Company. National Energy Balance, 2014. Available at: https://ben.epe.gov.br/ downloads/Relatorio_Final_BEN_2014.pdf [In Portuguese].

59.Opção Verde. Biomass consultancy. Available at: http://www.opcaoverde.com.br/biomassa [In Portuguese].

60.SOS SERTÃO, "Business Plan of the Malhada Association", p.39, 2014.

61.MFRURAL. Agribusiness starts here. Available: http://www.mfrural.com.br/busca.aspx?palavras=bagaco+cana [In Portuguese].

62.ENVALMA, Technical report. Available at: http://www.envalma.com/wa_files/Nota_20T_C3_A9cnica_203Metros_20Cubicos_20x_20Metro_20Estereo.pdf [In Portuguese].

63.J. L. P. Rezende, A. D. Oliveira, "Economic and Social analyses of forestry projects", MSc. dissertation, Federal University of Viçosa, 2001

64.Pellet Nordeste. Available: http://www.pelletsnordeste.com/?page_id=53\&lang=pt-br [In Portuguese].

65.J. C. A. Dornelas. "Entrepreneurship: transforming ideas in businesses," Elsevier, 2012.

66.M. Carvalho, M. A. Lozano, and L. M. Serra, "Multicriteria synthesis of trigeneration systems considering economic and environmental aspects", Applied Energy, 91.1, pp. 245-254, 2012.

67.M. Carvalho, L. M. Serra, and M. A. Lozano, "Optimal synthesis of trigeneration systems subject to environmental constraints", Energy 36.6 (2011): 3779-3790.

68.M. Carvalho, D. B. M. Delgado, "Potential of photovoltaic solar energy to reduce the carbon footprint of the Brazilian electricity matrix ", Revista Latino Americana de Avaliação do Ciclo de Vida - LALCA, vol. 1, n.1, pp. 64-85, 2017.

69.Ecoinvent database. Available at: http://www.ecoinvent.ch

70.Simapro software. Available at: http://www.simapro.nl 
71.IPCC. 2014. 2013 Revised Supplementary Methods and Good Practice Guidance Arising from the Kyoto Protocol. Available at: http://www.ipcc-nggip.iges.or.jp/public/kpsg/

72.D. B. M. Delgado, M. Carvalho, R. Chacartegui, L. M. Coelho Junior, "Optimization of energy supply and conversion in a northeast Brazil hospital: use of photovoltaic panels" In: 23rd ABCM Internationa Congress of Mechanical Engineering, 2015. 